\title{
Quinolones resistant enteric bacteria isolated from hawked kunun-zaki in selected parts of chikun local government area, kaduna state, Nigeria
}

\begin{abstract}
Two hundred samples of Kunun-zaki, an indigenous fermented non-alcoholic beverage were obtained from hawkers in five (5) different locations in Chikun Local Government of Kaduna State, Nigeria and screened for enteric bacteria. They were analyzed using Spread Plate Method. Four species of bacteria were isolated and identified by standard microbiological methods; these were Esherichia coli, Proteus vulgaris, Proteus mirabilis and Citrobacter freundii. The most predominant isolates in terms of percentage occurrence were: C.freundii $(100 \%)$, P.mirabilis $(60 \%)$ while E.coli and P.vulgaris had the least occurrence of (20\%) each respectively. Kirby-Bauer disk diffusion method was employed for the sensitivity testing. C. freundii showed high percentage resistance to Sparfloxacin $(14.29 \%)$, and the least percentage resistance were Ciprofloxacin, Pefloxacin and Tarivid $(7.14 \%)$ respectively. The highest percentage resistance for P.mirabilis was Sparfloxacin $(20 \%)$ while there was no resistance to the other antibiotics. For E. coli and P.vulgaris there was no resistance to any of the selected antibiotics. The antibiotic resistance pattern exhibited by C.freundii and P.mirabilis isolated from the Kunun-zaki hawked in Chikun is indicative of possible misuse of antibiotics and this has serious health implications. The results of this study demonstrate that Kunun-zaki sold in Chikun is contaminated with enteric bacteria including antibiotic resistant C.freundii and P.mirabilis and these may lead to failures in antibiotic chemotherapy among consumers of Kunun-zaki in the Chikun.
\end{abstract}

Keywords: quinolones, resistance, kunun zaki, enteric bacteria, chikun
Volume 4 Issue I - 2018

Katuka Yashim Blessed,' Anthony John Dadah,' Musa Jeremiah Yusuf,' Auwalu Uba 'Department of Microbiology, Kaduna State University, Nigeria ${ }^{2}$ Department of Microbiology, Abubakar Tafawa Balewa University Bauchi, Nigeria

Correspondence: Katuka Yashim Blessed, Department of Microbiology, Faculty of Science, Kaduna State University, Kaduna, Nigeria, Email blessedyashim@gmail.com

Received: January 24, 2018 | Published: February 09, 2018

\section{Introduction}

Quinolones are broad spectrum antibiotics, commonly used for the treatment of bacterial infections. Their mode of action involves inhibition of bacterial DNA synthesis by blocking the DNA gyrase. Food and drinks contaminated with antibiotic-resistant bacteria pathogens is a major threat to public health. ${ }^{2}$ As reported in 2015 by World Health Organization (WHO), quinolone is active against all enteropathogens bacteria and are therefore considered as drugs of choice for patients with severe enteric fever, severe gastroenteritis, cholera, etc. These enteric infections are common in sub-sahara African where an estimated nine hundred and sixty (960) to nine hundred and eighty (980) million people mostly young are at risk of infection. ${ }^{3}$ Globally there is an increase in the prevalence of antimicrobial resistance among foodborne pathogens in recent years due to unregulated use of antibiotics in animal and human food, poor sanitary conditions, etc. ${ }^{4}$

Oxford Concise Medical dictionary (2002) define enteric bacteria as rod shaped Gram negative bacteria. They occur normally or pathogenically in the intestines of humans and animals, are members of the family enterobacteriaceae which consist of forty four (44) genera namely: Citrobacter, Enterobacter, Proteus, Shigella, Yersinia, Klebsiella, Erwinia, Serratia, Salmonella, Shigella, Escherichia, etc. Some of them are primary pathogens, while some are opportunistic pathogens. Certain species are endemic to the hospital environment (i.e., Enterobacter sp., Klebsiella sp., Serratia sp.). They are also widely dispersed in nature present in soil, water, plants, normal flora of intestinal and genitourinary tracts of humans and animals. ${ }^{5-7}$ Enteric bacteria grow well on media, such as $5 \%$ sheep blood, chocolate, and MacConkey agars. In addition to these media, selective agar, such as Hektoen enteric (HE) agar, xylose-lysine-deoxycholate (XLD) agar, and Salmonella-Shigella (SS) agar, are commonly used to cultivate enteric pathogens from gastrointestinal specimens. ${ }^{8,9}$

"Kunun-Zaki" is a cereal based traditional fermented nonalcoholic, and noncarbonated beverage. ${ }^{10,11}$ The health benefit of Kunu-zaki include; increasing lactation in nursing mothers, serve as source of energy by providing important nutrients which contribute to the diet of the population. ${ }^{12}$ Kunun-zaki can also serve as vehicle for the transmission of pathogen if control measures are not observed during process. ${ }^{13}$

\section{Materials and methods}

\section{Collection of samples}

Forty (40) samples of Kunun-zaki were collected from each of the five (5) locations from different hawkers between the hours of 9:00am and 11:00am and between the months of May and August, 2016. The samples were collected in sterile plastic bottles using aseptic methods. The bottles were well labeled and immediately taken to the Microbiology laboratory of Kaduna State University (KASU) for processing.

\section{Isolation of bacteria from hawked kunu-zaki}

Salmonella Shigella Agar (SSA) (ANTEC) was employed for the isolation of bacteria for the purpose of identification. $0.1 \mathrm{ml}$ of 
the appropriately diluted kunun-zaki was used for the inoculation using spread plating method. The plates were incubated at $37^{\circ} \mathrm{C}$ for 24hours. The bacterial isolates were then identified following standard microbiological procedures based on cultural, morphological and biochemical characteristics as described by Amané et al. ${ }^{14}$

\section{Antimicrobial susceptibility test}

The isolates were screened for antimicrobial susceptibility using the Kirby-Bauer agar disk diffusion method (Clinical Laboratory Standard Institute CLSI, 2009). A suspension of each isolate was prepared in peptone water to match $0.5 \mathrm{McFarland}$ turbidity standards $\left(1.5 \times 10^{8} \mathrm{cfu} / \mathrm{ml}\right)$ in order to standardize the inoculum. The standardized inoculum of each isolate was inoculated in triplicates onto the surfaces of plain Mueller-Hinton agar plates. Sparfloxacin $(10 \mu \mathrm{g})$, Ciprofloxacin $(10 \mu \mathrm{g})$, Pefloxacin $(30 \mu \mathrm{g})$ and Tarivid $(10 \mu \mathrm{g})$ discs were placed and incubated at $37^{\circ} \mathrm{C}$ for 24 hours. The zones of inhibition were measured and compared with the Clinical and Laboratory Standards Institute (CLSI) guidelines. ${ }^{15}$

\section{Results}

Table 1 showed the results of the Cultural and Biochemical Characteristic of the probable organisms Isolated from Kunun-zaki. All the probable organisms were negative to oxidase and motile. Table 2 Shows the bacterial species isolated from Kunun-zaki samples obtained from different locations in Chikun. The isolates were $C$. freundii, E. coli, P.mirabilis and P.vulgaris. C.freundii was the most predominant isolate with very high percentage occurrence of $(100 \%)$, P.mirabilis (60\%) while E.coli and P.vulgaris had the least occurrence of $(20 \%)$ each. Table 3 Shows the Antibiotic resistance pattern of the bacterial species isolated from Kunun-zaki drinks obtained in Chikun. C. freundii exhibited very high percentage resistance to Sparfloxacin $(14.29 \%)$, and the least percentage resistance were Ciprofloxacin, Pefloxacin and Tarivid (7.14\%) respectively. The highest percentage resistance for P.mirabilis was Sparfloxacin $(20 \%)$ while there was no resistance to the other antibiotics. For E. coli and P.vulgaris there was no resistance to any of the selected antibiotics.

Table I Cultural and biochemical characteristic of enteric bacteria isolated from Kunun-zaki

\begin{tabular}{|c|c|c|c|c|c|c|c|c|c|c|c|c|c|}
\hline \multirow{2}{*}{$\begin{array}{l}\text { Isolate } \\
\text { code }\end{array}$} & \multirow{2}{*}{$\begin{array}{l}\text { Cultural } \\
\text { characteristic }\end{array}$} & \multirow[t]{2}{*}{ Urease } & \multirow[t]{2}{*}{ Oxidase } & \multirow[t]{2}{*}{ Citrate } & \multirow[t]{2}{*}{ Indole } & \multirow[t]{2}{*}{ Motility } & \multirow[t]{2}{*}{ MR } & \multirow[t]{2}{*}{ VP } & \multicolumn{3}{|l|}{ TSI } & \multicolumn{2}{|c|}{$\begin{array}{l}\text { Probable } \\
\text { organisms }\end{array}$} \\
\hline & & & & & & & & & Slope & Butt & H2S & Gas & \\
\hline$A$ & $\begin{array}{l}\text { Translucent } \\
\text { with grayshining } \\
\text { surface }\end{array}$ & + & - & + & - & + & + & - & $Y$ & $Y$ & + & + & $\begin{array}{l}\text { Citrobacter } \\
\text { freundeii }\end{array}$ \\
\hline B & $\begin{array}{l}\text { Transparent with } \\
\text { black center }\end{array}$ & + & - & + & - & + & + & - & $\mathrm{R}$ & $Y$ & + & + & $\begin{array}{l}\text { Proteus } \\
\text { mirabilis }\end{array}$ \\
\hline$C$ & $\begin{array}{l}\text { Transparent with } \\
\text { black center. }\end{array}$ & + & - & + & - & + & + & - & $\mathrm{R}$ & $Y$ & + & + & $\begin{array}{l}\text { Proteus } \\
\text { vulgaris }\end{array}$ \\
\hline $\mathrm{D}$ & $\begin{array}{l}\text { Smooth pink and } \\
\text { rosy }\end{array}$ & + & - & - & + & + & + & - & $Y$ & $Y$ & - & + & $\begin{array}{l}\text { Escherichia } \\
\text { coli }\end{array}$ \\
\hline
\end{tabular}

Key: $Y=$ Yellow (Acid reaction); $R=$ Red (Alkaline reaction); $(+)=$ Positive, $(-)=$ Negative; $M R=$ Methyl red; $V P=$ Voges Proskauer; Code $A=C$ itrobacter freundeii); Code $B=$ Proteus mirabilis; Code $C=$ Proteus vulgaris and Code $D=$ Escherichia coli.

Table 2 Bacterial isolates from samples of Kunun-zaki sold in different locations

\begin{tabular}{lllllll}
\hline \multirow{2}{*}{ Bacteria isolates } & \multicolumn{2}{l}{ Locations } & & & \\
\cline { 2 - 6 } & Mararaban-Rido & Sabon-Tasha & Narayi & Television & Kujama & Occurrence frequency (\%) \\
\hline C. freundii & + & + & + & + & + & 100 \\
P. mirabilis & - & + & + & + & - & 60 \\
P.vulgaris & + & - & - & - & - & 20 \\
E.coli & + & - & - & - & - & 20 \\
\hline
\end{tabular}

Table 3 Resistance pattern of bacterial isolates from kunun-zaki to some selective antibiotics

\begin{tabular}{|c|c|c|c|c|c|}
\hline S/No. & Antibiotics & & & & \\
\hline & Bacterial isolate & Ciprofloxacin ( $10 \mu g)$ & Sparfloxacin $(10 \mu g)$ & Pefloxacin $(30 \mu g)$ & Tarivid ( $10 \mu g)$ \\
\hline I & C. freundii & $I(7.14)$ & $2(14.29)$ & $I(7.14)$ & $I(7.14)$ \\
\hline 2 & E. coli & $0(0.00)$ & $0(0.00)$ & $0(0.00)$ & $0(0.000)$ \\
\hline 3 & P.mirabilis & $0(0.00)$ & $\mathrm{I}(20.00)$ & $0(0.00)$ & $0(0.00)$ \\
\hline 4 & P.vulgaris & $0(0.00)$ & $0(0.00)$ & $0(0.00)$ & $0(0.00)$ \\
\hline Total & & I & 3 & I & 1 \\
\hline
\end{tabular}




\section{Discussion}

The presence of C. freundii, E. coli, P.mirabilis and P.vulgaris isolated in kunun-zaki samples obtained from Chikun as showed in Table 2 revealed the contamination of the kunun-zaki with indicator organisms. The contamination could be from crude method of processing kunun-zaki, used of faecal contaminated water and dirty utensils for the preparation of the kunun-zaki, poor hygienic practice, exposing the kunun-zaki to dirty environment and lack of observation of the control measures used in the preparation of the kunun-zaki. This concurs with the work of ${ }^{16}$ who reported the presence of enteric bacterial in kunun-zaki sold in Keffi Metropolis of Nasarawa State.

The percentage occurrence of C. freundii E. coli, P.mirabilis and P.vulgaris in samples analyzed in all the locations were: C.freundii $(100 \%)$, P.mirabilis $(60 \%)$ while E.coli and P.vulgaris had the least occurrence of $(20 \%)$ each respectively as showed in Table 2 . The presence of all this bacteria are indication of the fact that the Kununzaki drink sold in the different locations in Chikun is contaminated with enteric bacteria and this might have come from crude method of processing kunun-zaki, used of faecal contaminated water and poor handling of the product during processing and sales of it respectively. This agree with the work of, ${ }^{17,18}$ who had reported that water used for production coupled with the crude method of production and packaging under poor sanitary conditions exposed the Kunun-zaki to microbial contamination. The source of contamination may also have come from the spices and additives used. ${ }^{19}$ To ensure the safety of kunun-zaki sold in Chikun Local Government, there is need to educate kunun-zaki hawkers through jingles, seminar and workshop on adequate control measure such as good hygiene practice, use of water that is free from contamination for processing of kunun-zaki so as to reducing the risk of infection by those that consumed it.

The sensitivity test revealed that all C.freundii isolated were resistant to all the selected quinolones namely Ciprofloxacin, Sparfloxacin, Pefloxacin and Tarivid. For P.mirabilis, it is resistant only to Sparfloxacin and susceptible to all the other quinolones. While E.coli and P.vulgaris are all susceptible to all the antibiotics. The percentage pattern of resistance are observed in Table 3. The multi drug resistance observed might probably be as a result of mutation in topoisomerase, decreased accumulation of quinolones in the bacterial cell and plasmid mediate quinolone resistance (PMQR).

\section{Acknowledgements}

We would like to show our gratitude to Ahyuwanie. E. Akanet for helping out with the funds for the publication. We are also grateful to the following people of Kaduna State university; Mr. Nathan Agog (Mathematical science), Mr. Reuben Kigbu, Mr. Mathew Bobai and Dr. S.S.D.Mohammed all from Microbiology Department for sharing their wisdom, and intellectual contribution to the original manuscript.

\section{Conflict of interest}

The author declares no conflict of interest.

\section{References}

1. Jawertz, Melnick, Adelbergs. Medical Microbiology. 23rd ed. UK McGraw-Hill Companies; 2007. 167 p.
2. Gajraj R, Pooransingh S, Hawker J, et al. Multiple outbreaks of Salmonella braenderup associated with consumption of iceberg lettuce. International Journal of Environmental Health Research. 2012;22(2):150-155.

3. World Health Organization (WHO). Food borne Diseases. Geneva: World Health Organization (WHO); 2015.

4. Nma ON, Oruese OM. Prevalence of Salmonella species and Escherichia coli in fresh Cabbage and Lettuce sold in Port Harcourt Metropolis, Nigeria. Report and Opinion. 2013;5(3):1-8

5. Garrity GM, Brenner DJ, Krieg NR, et al. Bergey's Manual of Systemat ic Bacteriology. 2nd ed. The Proteobacteria. Germany: SpringerVerlag; 2005. p. 587-607.

6. Forbes B, Sahm D, Weissfeld A. Bailey-Scotts Diagnostic Microbiology Nigeria; 2015.

7. Textbook of Diagnostic Microbiology. 3rd ed. Spain: Mahon; p. 212 224.

8. Baylis CL. Enterobacteriaceae. In: Clive de W, Blackburn, editors. Food spoilage microorganisms. UK: Woodhead publishing limited; 2006. p. 624-668.

9. Prescott LM, Harley JP, Klein DA. Microbiology textbook. 5th ed. UK McGraw-Hill; 2002. p. 963-971.

10. Akoma O, Agarry OO, Nkama I. The microbiological quality of freezedried Kunun-zaki during production and storage. International Journal of Biology, Pharmacy, and Allied Sciences. 2012;1(10):1397-1410.

11. Maji AA, Omale J, Chigozie OE. Effect of chemical treatment and pasteurization on the shelf life of Kunun zaki (sorghum and maize gruel). European Journal of Food Reserve. 2011;1(2):61-70.

12. Nyanzi R, Jooste PJ. Cereal-Based Functional Foods. South Africa; 2012.

13. Achi OK. The potential for upgrading traditional fermented foods through biotechnology. Africa Journal of Biotechnology. 2005;4(5):375-380.

14. Amané ND, Assidjo NE, Gbongue MA, et al. Caractérisation physicochimique d'une bière traditionnelle Ouest Africaine: le tchapalo. Journal of Africa. 2005;17(2):143-152.

15. Lawal OA. Microbial quality of Kunun-zaki beverage sold in Ile-Ife, Osun State. Journal of Food Technology. 2012;10(1):4-7.

16. Cheesbrough M. District Laboratory Practice in Tropical Countries. 1st ed. USA: Cambridge University Press; 2006. p. 135-140.

17. CLSI. Performance Standards for Antimicrobial Susceptibility Testing. Nineteenth Informational Supplement. USA: Clinical and Laboratory Standards Institute; 2009. 149 p.

18. Amusa NA, Ashaye OA. Microbiological and nutritional quality of hawked Kunun (a sorghumbased non-alcoholic beverage) widely consumed in Nigeria. Pakistan Journal of Nutrition. 2009;8(1):20-25.

19. Makut MD, Nyam MA, Obiekezie SO, et al. Antibiogram of Bacteria Isolated from Kunun-Zaki Drink Sold in Keffi Metropolis. American Journal of Infectious Diseases. 2013;9(3):71-76 